\title{
Diagnosis of Human Brucellosis by Amplification Reaction of BCSP31 Gene in Egyptian Patients
}

\author{
Sally Enany ${ }^{1,}$, , El- Ghareeb M. S. A. ${ }^{1}$, Zaghloul M. H.E. ${ }^{2}$ and Abdel-Aziz, A. F ${ }^{3}$ \\ ${ }^{1}$ Chemistry Department, Faculty of Science Port Said University, Egypt \\ ${ }^{2}$ Clinical Pathology Department, Faculty of Medicine Mansoura University, Egypt \\ ${ }^{3}$ Chemistry Department, Faculty of Science, Mansoura University, Egypt \\ "Corresponding author: saly anany@yahoo.com
}

\begin{abstract}
Background: Human brucellosis is a major public health issue in Egypt. Because the clinical signs of human brucellosis are so varied and vague, scientific confirmation via organism isolation or antibody detection is required to confirm the diagnosis. The aim of this work is measurement of the sensitivity and specificity of PCR for the detection of Brucella abortus BCSP31gene compared with the blood culture methods.

Methods: A total of 97 patients from different ages with symptoms of brucellosis were included in the study. This research study was carried out at Mansoura University Hospitals. The sensitivity and specificity of polymerase chain reaction (PCR) for the detection of BCSP31gene of Brucella abortus compared with blood culture methods.

Results: In positive PCR cases of brucella (total 14), a single band of a 223-bp corresponding to BCSP31gene was obtained. The true positive brucellosis cases $(n=6)$ are positive of blood culture and PCR. PCR was sensitive than blood culture for diagnosis of brucellosis since the sensitivity and specificity of PCR are $87.5 \%$ and $98.73 \%$ and the sensitivity and specificity of blood culture are $84.62 \%$ and $96.15 \%$. The positive and negative predictive values of PCR are $86.56 \%$ and $94.80 \%$ and the positive and negative predictive values of blood culture are $78.98 \%$ and $92.54 \%$. The accuracy (\%) of PCR and blood culture is $94.72 \%$ and $90.67 \%$. The PCR assay was shown to be more sensitive and specific.

Conclusion: The PCR showed higher efficiency for rapid diagnosis of human brucellosis, as compared to the blood culture method.

\section{Keywords}

Brucellosis, Brucella test, blood culture, PCR.
\end{abstract}

\section{INTRODUCTION}

Brucellosis was listed as one of the top ten zoonotic diseases in regards of effect on public health and the economy of disadvantaged communities, as well as one of the top five illnesses responsible for animal deaths around the world. [1].

Despite the fact that it has already been extinguished in several wealthy nations, it is still prevalent in most poor countries [2], especially in the Arab world [3]. It is a significant public health issue in Egypt, accounting for $3 \%$ of all occurrences of severe febrile disease [4].

Due to a high likelihood of treatment failure and consequent relapse, clinical care of brucellosis is one of the most difficult challenges [5]. Brucellosis diagnosis is commonly delayed and overlooked, particularly in developing nations [6].

Despite the development of numerous serological tests and innovative automated blood culture tools to identify brucellosis, there are also substantial challenges in the disease's diagnosis [8]. 
Serological, microbiological and molecular techniques are among the three methods used to diagnose brucellosis [9]. Although blood cultures are the standard method for laboratory confirmation, they are timeconsuming. Serology are more convenient than culture systems, however they have lower specificities [7].

Molecular biology approaches for detecting microorganisms are currently less time-consuming, offer great specificity, and sensitivity [29]. PCR is a sensitive, specific, quick, and easy-to-use choice for analysis and screening. It's also better for detecting bacteria that grow slowly, including Brucella. The PCR-based technique may detect very small amounts of bacteria in clinical specimens due to its great sensitivity. Brucella spp. detection techniques based on PCR have been designed and developed for clinical samples. These approaches are based on the amplification of the Brucella spp. gene BCSP31, which would be evolutionarily conserved [10, 29].

The aim of this study is to diagnose brucella infection by the amplification of BCSP31 gene.

\section{SUBJECTS AND METHODS}

This study comprised 97 patients from different ages experienced the clinical symptoms of brucellosis (acute and chronic brucellosis). This study was carried out at Mansoura University Hospitals in the period between January 2019 and September 2020. Patients signed a written consent form after the study was approved by the local ethics commission.

The patients with brucellosis were subjected to: complete history taking with special emphasis on clinical symptoms of brucellosis; including fever and arthritis.

\section{Brucella test:}

For patients with brucellosis, the CROMATEST stained antigens are standardized suspensions of killed bacteria prepared for the detection and semi-quantitation by agglutination in either slide or tube tests of human serum agglutinins, a group of antibodies developed during some febrile infections such as brucellosis, salmonellosis and certain rickettsiosis. The assay is performed by testing the stained antigens - somatic, blue; flagellar, red against unknown samples. The presence or absence of a visible agglutination is usually related with the presence or absence of the corresponding homologous antibody in the sample tested. Results are reported as a semiquantitative test. Positive samples were diluted to know the titre [30, 31].

\section{Blood culture examination:}

All samples were collected in BacT/ALERT bottles (BIOMERIEUX, USA) irrespective of antibiotics administration. Blood samples were subjected to automated blood culture system. Specific identification of all culture positive samples was accomplished by sub-culture on Blood agar, Chocolate agar and MacConkeys agar media (OXOID CO. UK). Inoculated Blood agar and MacConkeys agar plates were incubated aerobically at 37 oC. The Chocolate agar plates were incubated at $37 \mathrm{oC}$ under $5-10 \% \mathrm{CO}_{2}$ condition (Candle jar) and examined after 18-24 hours of incubation. Identification of growth was performed by VITEK 2 Compact system (bioMérieux,France) [11, 12].

Polymerase chain Reaction (PCR):1. Extraction of DNA: Extraction of DNA was done using the QIAamp DNA blood Kit (Qiagen) following the instructions published by the manufacturer [13]. The cells (maximum $2 \mathrm{x}$ $10^{9}$ cells) were harvested in a microcentrifuge tube by centrifugation for $10 \mathrm{~min}$ at $5000 \mathrm{xg}(7500 \mathrm{rpm})$, and then supernatant was discarded. The pellet was resuspended in $180 \mu \mathrm{l}$ Buffer ATL. The proteinase K $(20 \mu \mathrm{l})$ was added and was mixed thoroughly by vortexing, and then was incubated at $56^{\circ} \mathrm{C}$, and then was placed in a thermomixer to disperse the samples. Buffer AL $(200 \mu \mathrm{l})$ was added to the sample, and mix thoroughly by vortexing. Then $200 \mu \mathrm{l}$ of ethanol (96-100\%) was added, and mixed again thoroughly by vortexing. The mixture was pipetted into the DNeasy Mini spin column which was placed in a $2 \mathrm{ml}$ collection tube, and then was centrifuged at $\geq 6000 \times \mathrm{g}(8000 \mathrm{rpm})$ for $1 \mathrm{~min}$. The DNeasy Mini spin column was placed in a new $2 \mathrm{ml}$ collection tube (provided), then $500 \mu \mathrm{l}$ Buffer AW1 was added and centrifuge for $1 \mathrm{~min}$ at $\geq 6000 \mathrm{xg}(8000 \mathrm{rpm})$ to elute. The DNeasy Mini spin column was placed in a new $2 \mathrm{ml}$ collection tube (provided), and then buffer AW2 $(500 \mu \mathrm{l})$ was added, and was centrifuged for 3 minutes at 20,000 x g (14,000 rpm) to dry the DNeasy membrane. Flow-through and collection tube were discarded. The DNeasy Mini spin column was placed in a clean $2 \mathrm{ml}$ microcentrifuge tube, and $200 \mu \mathrm{l}$ Buffer AE was pipetted directly onto the DNeasy membrane and finally was incubated at room temperature for $1 \mathrm{~min}$, and then was centrifuged for $1 \mathrm{~min}$ at $\geq 6000 \mathrm{xg}(8000 \mathrm{rpm})$ to elute. For maximum DNA yield, the elution step was repeated once again.

2. Amplification and detection: For patients with brucellosis, The amplified area of a 223-bp portion of the brucella histidine transport operon was identified by oligonucleotide primers of 25 bp (BCSP31 gene). The 
forward and reverse oligonucleotide primer sequences, from $5^{\prime}$ to $3^{\prime}$, will be as follows: strand forward, TGGCTCGGTTGCCAATATCAA; reverse strand CGCGCTTGCCTTTCAGGTCTG [14, 15, 16].

3. Conventional PCR optimization: The initial part of PCR optimisation was performed using conventional PCR. Each reaction in a total of $25 \mu \mathrm{L}$ contained $12.5 \mu \mathrm{L}$ PCR Master Mix (Promega, USA), $1 \mu \mathrm{L}$ each of the forward and reverse primers, $5 \mu \mathrm{L}$ of DNA template and $5.5 \mu \mathrm{L}$ molecular grade water. The primer concentration used in the reaction was kept constant at $10 \mu \mathrm{M}$. Amplification was performed in Stepone thermal cycler. Annealing temperature optimisation was performed at 12 points using the following condition; initial denaturation at $94{ }^{\circ} \mathrm{C}$ for $2 \mathrm{~min}$ followed by 35 cycles of $94{ }^{\circ} \mathrm{C}$ denaturation for $1 \mathrm{~min}$, annealing at $49.8{ }^{\circ} \mathrm{C}$ to $65.1{ }^{\circ} \mathrm{C}$ for 1 min and extension, $72{ }^{\circ} \mathrm{C}$ for $1 \mathrm{~min}[17,18]$. PCR products $(5 \mu \mathrm{L})$ were electrophoresed on $2 \%$ agarose gel in a $0.5 \times$ TBE buffer at $85 \mathrm{~V}$ for $60 \mathrm{~min}$. The gel was stained with GelRed ${ }^{\mathrm{TM}}$ (Biotium ${ }^{\circledR}, \mathrm{USA}$ ). A $50 \mathrm{bp}$ DNA ladder (Fermentas, USA) was included as the molecular weight marker in every electrophoresis run. The PCR products were visualised under ultraviolet (UV) illumination using gel image documentation system (GelDoc 1000 system, Bio-Rad, USA).

A statistical software programmed has been used to analyse the data (SPSS for Windows, version 21, USA). The findings of all statistical tests were deemed significant at $\mathrm{P}$-value $\leq 0.05$.

\section{RESULTS}

On blood samples of 97 patients, PCR was carried out for BCSP31 gene was positive in 14 patients.

The amplified portion of a 223-bp fragment of BCSP31 gene was identified using 25-bp oligonucleotide primers and at the end of the PCR, the amplified product was identified. A total of 83 patients had negative PCR test results.

The PCR for BCSP31 gene of brucella yielded a sensitivity of $87.5 \%$ and yielded a specificity of $98.73 \%$. The PCR's positive predictive value (PPV) was shown to be $86.56 \%$ with a precision and an accuracy of 94.72 $\%$. The PCR findings were statistically significant $(\mathrm{P}=0.001)$.

Table 1. The validity of Blood culture and PCR test as a diagnostic tool for Brucellosis

\begin{tabular}{lcc}
\hline & Blood culture & PCR \\
\hline AUC & 0.012 & 0.012 \\
Sensitivity (\%) & 84.62 & 87.5 \\
Specificity (\%) & 96.15 & 98.73 \\
PPV (\%) & 78.98 & 86.56 \\
NPV (\%) & 92.54 & 94.80 \\
Accuracy (\%) & 90.67 & 94.72 \\
Standard error & 0.010 & 0.010 \\
CI 95 \% & $0.008-0.031$ & $0.008-0.032$ \\
P - value & 0.001 & 0.001 \\
\hline
\end{tabular}

Table 1 Blood culture and PCR test were shown to be valid diagnostic tools for Brucellosis. For Brucellosis diagnosis, PCR was more sensitive than blood culture. 
Table 2. Association between brucella titre and other diagnostic methods; blood culture and PCR in patients with brucella

\begin{tabular}{lllll}
\hline & \multicolumn{3}{l}{ Plood culture } & PCR \\
\cline { 2 - 5 } & Negative & Positive & Negative & Positive \\
\hline Brucella titre & & & $62(74.7 \%)$ & $1(7.1 \%)$ \\
$\mathbf{1 / 8 0}$ & $59(68.6 \%)$ & $4(36.4 \%)$ & $16(19.3 \%)$ & $0(0 \%)$ \\
$\mathbf{1 / 1 6 0}$ & $16(18.6 \%)$ & $0(0 \%)$ & $5(5 \%)$ & $7(50 \%)$ \\
$\mathbf{1 / 3 2 0}$ & $9(10.5 \%)$ & $3(27.3 \%)$ & $0(0 \%)$ & $6(42.9 \%)$ \\
$\mathbf{1 / 6 4 0}$ & $2(2.3 \%)$ & $4(36.4 \%)$ & $83(100 \%)$ & $14(100 \%)$ \\
\hline Total & $86(100 \%)$ & $11(100 \%)$ & $\begin{array}{l}\text { Chi-Square value }=65.414 \\
\text { P-value }=0.001\end{array}$ \\
\hline
\end{tabular}

Table 2 summerizes the correlation between brucella titre and other diagnostic methods; blood culture and PCR in patients with brucella. There was a significant association between brucella titre and blood culture $(p=0.001)$ in patients with brucella. Furthermore, there was a significant association between brucella titre and PCR ( $\mathrm{p}=$ 0.001 ) in patients with brucella.

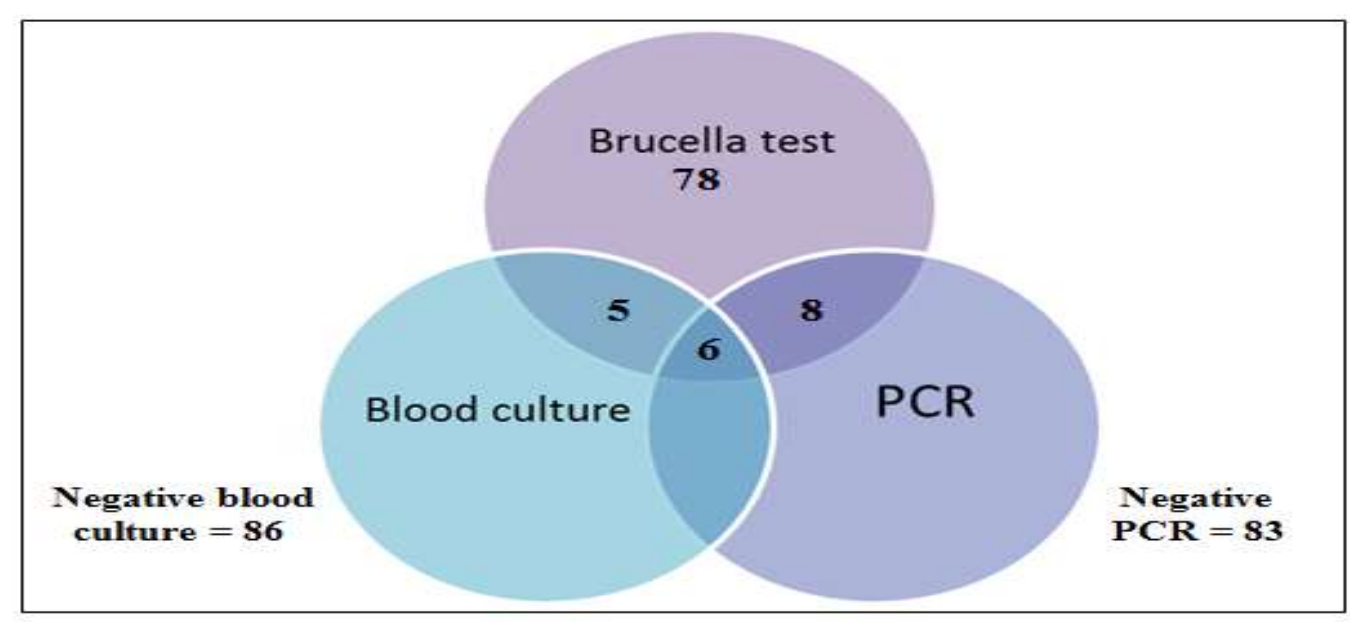

Figure 1. Venn diagram showing number of positive results in each combination of Brucella test, blood culture and PCR $(n=97)$. The true positive brucellosis cases $(n=6)$ are positive of brucella test, blood culture and /or PCR. 


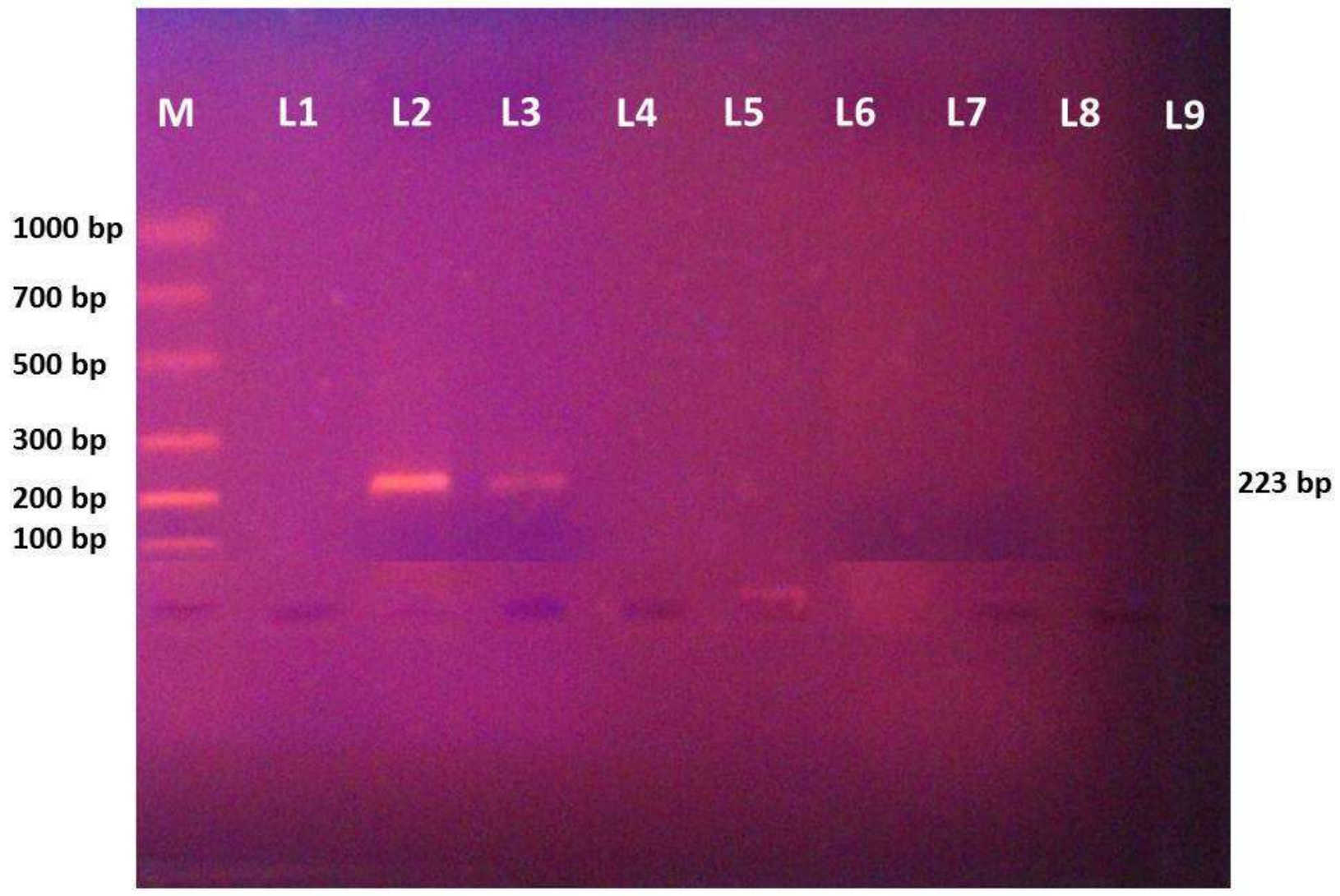

Figure 2. After amplification of gene-specific DNA fragments from a blood sample for brucellosis patients, Standard PCR amplicons electrophoresis on an agarose gel was performed. Electrophoresis on 3 percent (w/v) agarose gels was used to examine the samples. DNA was seen under UV light after gels were stained with ethidium bromide. This results in amplicons $223 \mathrm{bp}$.

\section{DISCUSSION}

Because the symptoms of brucellosis are ambiguous and often atypical, the clinical picture alone cannot usually lead to a diagnosis [8].

Serological assays are utilised for both the initial diagnosis of infection and the monitoring of treatment outcomes. After a successful treatment, the antibody titer should decrease [25].

Despite the fact that culture is the Gold standard' in microbiological identification, culture can sometimes be wiped off by elements inherent to the bacterium itself despite careful laboratory procedures. The use of PCR to detect culture negative patients with brucellosis symptoms backed up this theory [7, 25].

Brucella DNA can be amplified and detected using PCR in samples or cultures. To amplify and detect specific gene sequence of a genus, species, or indeed genotypes of Brucella, numerous single-step PCR techniques have been devised. The primer for the sequence encoding BCSP31 is one of the primer pairs used to detect Brucella at the genus level [25].

PCR was once thought to be the gold standard for brucellosis diagnosis as suggested by [21], For brucellosis diagnosis, he claims that this procedure is more accurate than culture as well as serology. Also, [22] stated that PCR is a significant technique not only for diagnosing acute brucellosis, as well as for predicting the progression of the disease as well as post-treatment follow-up, which is important for detecting relapses early.

[26] revealed that PCR with several gene targets has become the most prevalent method of diagnosing brucellosis in humans and animals. Despite the fact that it is much more sensitive, faster and so less hazardous than cultural methods. Another method of diagnosis used in their study was culture isolation followed by PCR confirmation, because PCR confirmation can quickly identify species at the species level.

In the present study, PCR standardized for the gene encoding a 31-kDa Brucella abortus "BCSP31" gene result in specific amplicon of 223-bp. In positive

PCR cases of brucella (total 14), a single band of $223 \mathrm{bp}$ 
corresponding to BCSP31 gene was obtained. PCR was sensitive than blood culture for diagnosis of brucellosis since the sensitivity and specificity of PCR are $87.5 \%$ and $98.73 \%$ respectively and the sensitivity and specificity of blood culture are $84.62 \%$ and $96.15 \%$ respectively. The positive predictive value of PCR is $86.56 \%$ and the positive predictive value of blood culture is $78.98 \%$. The accuracy (\%) of PCR and blood culture are $94.72 \%$ and $90.67 \%$ respectively.

We concluded that PCR was sensitive than blood culture for diagnosis of brucellosis.

These results agree with that shown by [4], they employed blood culture as a standard and discovered that their PCR approach had a 100\% sensitivity. Because of its great sensitivity in culture-positive patients, PCR may be able to take the place of blood culture as the gold standard for acute brucellosis diagnosis. [4], found in their investigation that the PCR positives increased dramatically as seropositivity increased.

[7], found that blood culture had a low sensitivity for isolating Brucella, and the average incubation period for positive cultures was considerable and found that the stage and severity of the disease may alter the sensitivity of PCR. This could explain why the PCR sensitivity in their analysis was lower than in earlier investigations. Furthermore, they discovered that the PCR method may be essential. In a study accompanied by [19], when multiple PCR methods for diagnosing brucellosis were compared, it was discovered that PCR was more sensitive. Hedayati et al, established a better PCR technique for the quick and specific identification of acute brucellosis in the laboratory using serum samples from 30 patients. A crucial aspect to consider in the research of [7], the sensitivity of serum PCR was higher than that of whole blood PCR [20].

[23], reported that conventional PCR has a sensitivity of 95.89 percent and a specificity of 93 percent. [24], found that PCR can be used to detect brucella DNA directly in blood samples taken from people who have brucellosis. Because DNA from patients with acute and chronic brucellosis was amplified and a 223-bp segment similar with that of the positive controls was created, the test is also exclusive for Brucella species. The assay is extremely quick, delivering data to the clinician in less than 24 hours [24].

Isolation of Brucella spp. from specimens is still the standard method for diagnosing Brucellosis. PCRbased approaches for identifying genomic DNA fragments from bacteria, on the other hand, are more helpful and useful [28].

[27], reported PCR results were 51.3 percent accurate with a sensitivity of 12.6 percent and a specificity of 100 percent, indicating that fast assays like PCR can help with early case reports. Although PCR will be the final diagnostic method for quick human brucellosis diagnosis [4], recommend accomplishment a broader investigation in all Egyptian governorates to develop a titer for brucellosis serodiagnosis.

\section{CONCLUSION}

The PCR showed higher efficiency for rapid diagnosis of human brucellosis, as compared to the blood culture method.

\section{REFRENCES}

[1] Bodenham R, Lukambagire A, Ashford R, Buza J, Goldwasser S, Crump J, Kazwala R, Maro V, McGiven J, Mkenda N, Mmbaga B, Rubach M, Sakasaka P, Shirima G, Swai E, Thomas K, Whatmore A, Haydon D and Halliday J (2020). Scientific Reports (2020) 10:7081. DOI:10.1038/s41598-02062849-4.

[2] Qasem J, AlMomin S, Al-Mouqati S and Kumar V (2015). Saudi Journal of Biological Sciences, 22, 220-226. DOI: 10.1016/j.sjbs.2014.09.014.

[3] NejadID R, KrecekID R, Khalaf O, Hailat N, Arenas-Gamboa A (2020). Trop Dis 14(5): e0008071. https://doi.org/10.1371/journal.pntd.0008071.

[4] Marei A, Boghdadi G, Abdel-Hamed N, Hessin R, Abdoel T, Smits H and Fathey F (2011). J Infect Dev Ctries. 15;5(11):786-91. doi: 10.3855/jidc.1538.

[5] Alavi S and Alavi L (2013). Caspian J Intern Med. 4(2):636-41. https://www.ncbi.nlm.nih.gov/pmc/articles/PMC3755828.

[6] Franc K, Krecek R, Hasler B and Arenas-Gamboa A (2018). BMC Public Health; 18(1):125. DOI:10.1186/s12889-017-5016-y.

[7] Alikhani M, Hashemi S, Naseri Z, Farajnia S and Dogaheh H (2013). Jundishapur J. Microbiol., 6(3):248-51. DOI : $10.5812 / \mathrm{jjm} .5073$.

[8] Hassanain N and Ahmed W (2012). World Journal of Medical Sciences, 7 (4): 243-247. DOI:10.5829/idosi.wjms.2012.7.4.65190. 
[9] Garshasbi M, Ramazani A, Sorouri R, Javani S and Moradi S (2014). Brazilian Journal of Microbiology 45, 2, 533-538. doi: 10.1590/s1517-83822014005000048.

[10] Abu Sulayman S, Bora R, Sabir J and Ahmed M (2020). Advancements of microbiology, 59, 4, 337344. https://doi.org/10.21307/PM-2020.59.4.25.

[11] Habeb K, Mohammed I and Faik A (2014). International Journal of Advanced Research, Volume 2, Issue 1, 663-671. https://pubmed.ncbi.nlm.nih.gov/16258407/.

[12] Singh L and Cariappa M (2016). Medical journal, Armed Forces India, 72(3), 281-284. doi: 10.1016/j.mjafi.2015.07.007. Epub 2015 Sep 4.

[13] DNeasy® Blood \& Tissue Handbook, 2006. DNeasy Blood \& Tissue Kit - DNeasy 96 Blood \& Tissue Kit For purification of total DNA from animal blood, animal tissue, rodent tails, ear punches, cultured cells, fixed tissue, bacteria, and insects. 2006 QIAGEN. URL: http://www.bea.ki.se/documents/ENDNeasy\%20handbook.pdf

[14] Romero C, Gamazo C, Pardo M and López-Goñi I (1995). J Clin Microbiol; 33(3):615-7. doi: 10.1128/jcm.33.3.615-617.1995.

[15] Ratushna V, Sturgill D, Ramamoorthy S (2006). BMC Microbiol 6, 13. DOI:10.1186/1471-2180-6-13.

[16] Moulana Z, Roushan M and Marashi S (2016). Electronic physician, 8(11), 3222-3227. doi: $10.19082 / 3222$.

[17] Zhou L and Pollard A (2010). Ann Clin Microbiol Antimicrob. 19;9:14. DOI:10.1186/1476-0711-9-14.

[18] Thakur S, Bedi J, Singh R, Gill J, Arora A and Kashyap N (2018). J Infect Public Health; 11(4):514520. DOI:10.1016/j.jiph.2017.10.004.

[19] Al-Ajlan H, Ibrahim A and Al-Salamah A (2011). Pol J Microbiol; 60(1):27-33. doi: 10.1111/j.1574695X.2002.tb00616.x.

[20] Schlabritz-Loutsevitch N, Whatmore A and Quance C (2009). J Med Primatol; 38: 70-3. doi: 10.1111/j.1600-0684.2008.00314.x.

[21] Maher A (2010). Evaluation of Rose Bengal test in comparison with PCR for diagnosis of human brucellosis, M. Sc. Thesis, Faculty of Medicine, Ain Shams University, Egypt.

[22] Mitka S, Anetakis C, Souliou E, Diza E and Kansouzi A (2007). J. Clin. Microbiol., 10: 1128. doi: 10.1128/JCM.00010-06.

[23] AL-Garadia M, Khairani-Beio S, Zunita Z and Omar A (2011). J. Anim. Vet. Adv., 10: 1437-1444. DOI:10.3923/javaa.2011.1437.1444.

[24] Matar G, Khneisser I and Abdelnoor A (1996). JOURNAL OF CLINICAL MICROBIOLOGY, p. 477— 478. DOI:10.1128/JCM.34.2.477-478.1996.

[25] Etemadi A, Moniri R, Neubauer H, Goli Y and Alamian S (2019). Jundishapur J Microbiol; 12(5). DOI : $10.5812 / \mathrm{jjm} .91200$

[26] Xavier M, Paixao T , Hartigh A, Tsolis R and Santos R (2010). The Open Veterinary Science Journal, 4, 109-118. DOI: 10.2174/1874318801004010109.

[27] Gemechu M, Gill J, Arora A and Ghatak S (2011). Int J Prev Med.; 2(3): 170-177. https://www.ncbi.nlm.nih.gov/pmc/articles/PMC3143531/.

[28] Yu W and Nielsen K (2010). Croat Med J; 51: 306-13. DOI: 10.3325/cmj.2010.51.306.

[29] Rahbarnia L, Farajnia S, Naghili B and Saeedi N (2021). Arch Razi Inst.76(2):203-211. Doi: 10.22092/ARI.2020.127122.1371.

[30] Wilson G, Miles A (1974). Topley and Wilson's principles of bacteriology, virology and immunity. 9:2355-2357.

[31] Hudderson L, Abell E (1928). J. infect. Dis. 42(8):242. https://doi.org/10.1093/infdis/42.3.242. 